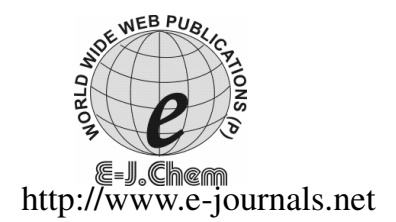

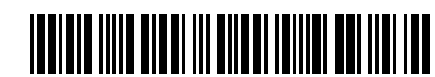

ISSN: 0973-4945; CODEN ECJHAO

E-Journal of Chemistry

2012, 9(1), 289-293

\title{
Facile and Selective Synthesis of 2-Substituted Benzimidazoles Catalyzed by $\mathrm{FeCl}_{3} / \mathrm{Al}_{2} \mathrm{O}_{3}$
}

\author{
GUO-FENG CHEN* and XIAO-YUN DONG
}

Key Laboratory of Medical Chemistry and Molecular Diagnosis, Ministry of Education, College of Chemistry and Environmental Science, Hebei University, Baoding 071002, P. R. China

chenguofeng@hbu.cn

Received 29 April 2011; Accepted 13 July 2011

\begin{abstract}
Substituted benzimidazoles were synthesized in a single pot from aromatic aldehydes and $o$-phenylenediamine catalyzed by $\mathrm{FeCl}_{3} / \mathrm{Al}_{2} \mathrm{O}_{3}$ in DMF at ambient temperature attained good yields and high selectivity.
\end{abstract}

Keywords: Benzimidazoles, $o$-Phenylenediamine, Aromatic aldehyde, $\mathrm{FeCl}_{3} / \mathrm{Al}_{2} \mathrm{O}_{3}$

\section{Introduction}

Benzimidazole derivatives are important intermediates with their good biological and pharmacological properties in the organic synthesis ${ }^{1}$. They exhibit significant activity against several viruses such as $\mathrm{HIV}^{2}$ herpes (HSV-1) ${ }^{3}$ and RNA influenza ${ }^{4}$. Methods of benzimidazole synthesis include the condensation of $o$-aryldiamines and carboxylic acids ${ }^{5}$ or its derivatives ${ }^{6}$ in the presence of strong acids and even sometimes combined with very high temperature ${ }^{7}$. The other method is that benzimidazoles have been prepared by classical cyclocondensation of $o$-phenylenediamine and aldehydes under oxidative conditions employing sulfamic acids ${ }^{8}, \mathrm{I}_{2}{ }^{9}$, $\mathrm{In}(\mathrm{OTf})_{3}{ }^{10}, \quad \mathrm{Sc}(\mathrm{OTf})_{3}{ }^{11}$, activated carbon $^{12}, \quad \mathrm{FeCl}_{3} \cdot 6 \mathrm{H}_{2} \mathrm{O}^{13}, \quad \mathrm{H}_{2} \mathrm{O}_{2} / \mathrm{HCl}^{14}, \quad$ sulfonic acid functionalized silica ${ }^{15}, \mathrm{DDQ}^{16}, \mathrm{NH}_{4} \mathrm{OAc}^{17}, \mathrm{IL}^{18}$, (bromodimethyl)sulfonium bromide ${ }^{19}$, iodobenzene diacetate ${ }^{20}$, air ${ }^{21}$, AlKIT- ${ }^{22}$, mono and bifunctional solid Catalysts ${ }^{23}$, scolecite ${ }^{24}$, Copper(I) Chloride ${ }^{25}$, manganese(III) acetate ${ }^{26}$, silica-supported thionyl chloride ${ }^{27}$ and $\operatorname{SDS}^{28}$ as catalysts. Unfortunately, some of these methods have one or more drawbacks such as expensive reagents, drastic reaction conditions, low yields, tedious work up procedures and co-occurrence of several side reactions. Therefore, the discovery of mild and practical routes for synthesis of 2-substituted benzimidazoles continues to attract the attention of researchers.

Catalysts and reagents supported on inorganic substrates have received increasing attention in recent years as a means to develop more convenient or selective catalysts or reagents ${ }^{29}$. As reported in previous papers, ferric chloride adsorbed on alumina has been used as the catalyst in the preparation of 2 -amino-2-hydroxy-1,1'-binaphthyl ${ }^{30}, 1,1^{\prime}$-bina 
phthalene-2,2'-diol ${ }^{31}$ and diphenylmethane ${ }^{32}$ to afford the desired products in higher yields. All of these results of $\mathrm{FeCl}_{3} / \mathrm{Al}_{2} \mathrm{O}_{3}$ spurred us to study its application for the synthesis of benzimidazoles, a very useful intermediates/subunits for the development of molecules of pharmaceutical or biological interest (Scheme 1).<smiles>Nc1ccccc1N</smiles>

1
$+\mathrm{RCHO} \frac{\mathrm{FeCl}_{3} / \mathrm{Al}_{2} \mathrm{O}_{3}}{\mathrm{DMF}, 25^{\circ} \mathrm{C}}$

2<smiles>[R]c1nc2ccccc2[nH]1</smiles>

(major)<smiles>[R]Cn1c([R])nc2ccccc21</smiles>

\section{Experimental}

Scheme1. Synthesis of benzimidazoles

All chemicals were obtained from commercial suppliers and used without further purification. Melting points were uncorrected. ${ }^{1} \mathrm{H}$ NMR spectra were recorded on a Bruker AVANCE $600(600 \mathrm{MHz})$ spectrometer using TMS as internal standard and DMSO- $\mathrm{d}_{6}$ as solvent. Mass spectra were determined on a Agilent Technologies 6310 Lon Trap LC/MS.

Preparation of the catalyst $\left(\mathrm{FeCl}_{3} / \mathrm{Al}_{2} \mathrm{O}_{3}\right)$

The $\mathrm{FeCl}_{3} / \mathrm{Al}_{2} \mathrm{O}_{3}$ was prepared by reported method ${ }^{33}$ by mixing with $\sim 10 \%$ its weight of hydrated ferric chloride $\left(\mathrm{FeCl}_{3} \cdot 6 \mathrm{H}_{2} \mathrm{O}\right) 8 \mathrm{~g}$ in acetone $(72 \mathrm{~mL})$ and adding $43.2 \mathrm{~g}$ neutral $\mathrm{Al}_{2} \mathrm{O}_{3}$. The mixture was stirred at room temperature for $1 \mathrm{~h}$. The acetone was removed under reduced pressure. The resulting yellow-brown powder was dried at $120{ }^{\circ} \mathrm{C}$ for $4 \mathrm{~h}$.

\section{General procedure for the Synthesis of 2-substituted benzimidazoles}

$o$-Phenlyenediamine $(\mathbf{1}, 1 \mathrm{mmol})$ and aromatic aldehyde $(2,1 \mathrm{mmol})$ were dissolved in DMF $(2 \mathrm{~mL})$ in a $25 \mathrm{~mL}$ tapered Pyrex flask, the $\mathrm{FeCl}_{3} / \mathrm{Al}_{2} \mathrm{O}_{3}\left(160 \mathrm{mg}, 0.1 \mathrm{mmol}\right.$, based on $\left.\mathrm{FeCl}_{3}\right)$ was then added and the mixture was stirred at $25^{\circ} \mathrm{C}$ for the specified time as indicated in Table 1-3. The reaction was followed by TLC. After the completion of the reaction, the mixture was dissolved in ethyl acetate, and the catalyst was removed by filtration and washed with ethyl acetate. The solvent was evaporated under pressure to give the crude product, which was purified by column chromatography on silica gel eluted with petroleum ether or the mixture of EtOAc and petroleum ether. All of the compounds were identified by comparing their melting points with that reported in literatures ${ }^{8,24,27}$ and characterized by ${ }^{1} \mathrm{H}$ NMR and mass spectra.

\section{2-(3'-Chlorophenyl)benzimidazole (3c)}

Isolated as white crystal. ${ }^{1} \mathrm{H}$ NMR $\delta: 13.05(\mathrm{~s}, 1 \mathrm{H}), 8.23(\mathrm{~d}, 1 \mathrm{H}, J=1.0 \mathrm{~Hz}), 8.15\left(\mathrm{dd}, 1 \mathrm{H}, J_{1}=\right.$ $\left.7.5 \mathrm{~Hz}, J_{2}=0.9 \mathrm{~Hz}\right), 7.69$ (s, 1H), 7.56-7.61 (m, 3H), $7.24(\mathrm{~s}, 2 \mathrm{H})$; MS (ESI) $m / z: 229[\mathrm{M}+\mathrm{H}]^{+}$.

\section{2-(2'-Nitrophenyl)benzimidazole (3e)}

Isolated as yellow crystal. ${ }^{1} \mathrm{H}$ NMR $\delta: 13.07(\mathrm{~s}, 1 \mathrm{H}), 8.04(\mathrm{~d}, 1 \mathrm{H}, J=8.4 \mathrm{~Hz}), 7.99(\mathrm{dd}, 1 \mathrm{H}$, $\left.J_{1}=7.6 \mathrm{~Hz}, J_{2}=1.0 \mathrm{~Hz}\right), 7.86-7.89(\mathrm{~m}, 1 \mathrm{H}), 7.75-7.78(\mathrm{~m}, 1 \mathrm{H}), 7.67(\mathrm{~d}, 1 \mathrm{H}, J=7.8 \mathrm{~Hz})$, $7.58(\mathrm{~d}, 1 \mathrm{H}, J=7.9 \mathrm{~Hz}), 7.28(\mathrm{t}, 1 \mathrm{H}, J=7.8 \mathrm{~Hz}), 7.23(\mathrm{t}, 1 \mathrm{H}, J=7.8 \mathrm{~Hz})$; MS (ESI) $m / z$ : $240[\mathrm{M}+\mathrm{H}]^{+}$.

\section{2-(3'-Nitrophenyl)benzimidazole (3f)}

Isolated as yellow crystal. ${ }^{1} \mathrm{H}$ NMR $\delta: 13.29(\mathrm{~s}, 1 \mathrm{H}), 9.00(\mathrm{t}, 1 \mathrm{H}, J=1.8 \mathrm{~Hz}), 8.60(\mathrm{~d}, 1 \mathrm{H}, J$ $=7.9 \mathrm{~Hz}), 8.31\left(\mathrm{dd}, 1 \mathrm{H}, J_{1}=8.0 \mathrm{~Hz}, J_{2}=1.6 \mathrm{~Hz}\right), 7.84(\mathrm{t}, 1 \mathrm{H}, J=8.0 \mathrm{~Hz}), 7.72(\mathrm{~d}, 1 \mathrm{H}, J=$ $7.8 \mathrm{~Hz}), 7.58(\mathrm{~d}, 1 \mathrm{H}, J=7.7 \mathrm{~Hz}), 7.22-7.29(\mathrm{~m}, 2 \mathrm{H})$; MS (ESI) $m / z: 240[\mathrm{M}+\mathrm{H}]^{+}$. 


\section{2-(4'-Methylphenyl)benzimidazole (3h)}

Isolated as light yellow crystal. ${ }^{1} \mathrm{H}$ NMR $\delta: 12.83(\mathrm{~s}, 1 \mathrm{H}), 8.07(\mathrm{~d}, 2 \mathrm{H}, J=8.1 \mathrm{~Hz}), 7.64$ (s, 1H), $7.52(\mathrm{~s}, 1 \mathrm{H}), 7.36(\mathrm{~d}, 2 \mathrm{H}, J=7.9 \mathrm{~Hz}), 7.20(\mathrm{~s}, 2 \mathrm{H}), 2.38(\mathrm{~s}, 3 \mathrm{H})$; MS (ESI) $\mathrm{m} / z: 209$ $[\mathrm{M}+\mathrm{H}]^{+}$.

\section{2-[4'-(N,N-Dimethylaminophenyl)]benzimidazole (3i)}

Isolated as light yellow crystal. ${ }^{1} \mathrm{H}$ NMR $\delta: 12.54(\mathrm{~s}, 1 \mathrm{H}), 7.99-8.01(\mathrm{~m}, 2 \mathrm{H}), 7.50(\mathrm{~s}, 2 \mathrm{H})$, 7.12-7.14 (m, 2H), 6.80-6.88 (m, 2H), 2.97 (s, 6H); MS (ESI) m/z: $238[\mathrm{M}+\mathrm{H}]^{+}$.

\section{2-(2'-Furanylphenyl)benzimidazole (3j)}

Isolated as light yellow crystal. ${ }^{1} \mathrm{H}$ NMR $\delta$ : $12.93(\mathrm{~s}, 1 \mathrm{H}), 7.95(\mathrm{~d}, 1 \mathrm{H}, J=1.2 \mathrm{~Hz}), 7.57$ (s, 2H), 7.19-7.22 (m, 3H), 6.73-6.74 (m, 1H); MS (ESI) m/z: $185[\mathrm{M}+\mathrm{H}]^{+}$.

\section{2-(3',4'-Methylenedioxyphenyl)benzimidazole (3k)}

Isolated as light yellow crystal. ${ }^{1} \mathrm{H}$ NMR $\delta: 12.77(\mathrm{~s}, 1 \mathrm{H}), 7.73\left(\mathrm{dd}, 1 \mathrm{H}, J_{1}=8.1 \mathrm{~Hz}, J_{2}=1.6\right.$ $\mathrm{Hz}), 7.70(\mathrm{~d}, 1 \mathrm{H}, J=1,6 \mathrm{~Hz}), 7.57$ (s, 2H), 7.17-7.20 (m, 2H), $7.10(\mathrm{~d}, 1 \mathrm{H}, J=8.0 \mathrm{~Hz}), 6.13$ $(\mathrm{s}, 2 \mathrm{H}) ; \mathrm{MS}(\mathrm{ESI}) \mathrm{m} / z: 239[\mathrm{M}+\mathrm{H}]^{+}$.

\section{Results and Discussion}

In order to get the best experimental condition, we have considered the reaction of $o$-phenylenediamine (1) and benzaldehyde (2a) in the presence of $\mathrm{FeCl}_{3} / \mathrm{Al}_{2} \mathrm{O}_{3}$ with stirring at ambient temperature as a standard model reaction. The effect of solvent on the reaction was studied. As shown in Table 1, when the reaction was run in DMF, the yield of 2-phenyl-1H-benzimidazole (3a) was found relatively better (Entry 6). Therefore, DMF was selected as the choice of solvent for this reaction. When the reaction was run in nitrogen atmosphere, 3a was obtained in 59\% yield (Entry 7). These results suggest that aerial oxygen played an oxidant role in this reaction.

Table 1. List of optimal solvent for the synthesis of 2-phenyl-1H-benzimidazole (3a) ${ }^{\mathbf{a}}$

\begin{tabular}{cccccc}
\hline Entry & Catalyst & Solvent & Time, $\mathrm{h}$ & Yield $^{\mathrm{b}}(\mathbf{3 a}), \%$ & Yield $^{\mathrm{b}}(\mathbf{4 a}), \%$ \\
\hline 1 & $\mathrm{FeCl}_{3} / \mathrm{Al}_{2} \mathrm{O}_{3}$ & $\mathrm{CH}_{3} \mathrm{OH}$ & 0.7 & 46 & 43 \\
2 & $\mathrm{FeCl}_{3} / \mathrm{Al}_{2} \mathrm{O}_{3}$ & $\mathrm{C}_{2} \mathrm{H}_{5} \mathrm{OH}$ & 0.6 & 55 & 45 \\
3 & $\mathrm{FeCl}_{3} / \mathrm{Al}_{2} \mathrm{O}_{3}$ & $\mathrm{CH}_{2} \mathrm{Cl}_{2}$ & 4.2 & 57 & 42 \\
4 & $\mathrm{FeCl}_{3} / \mathrm{Al}_{2} \mathrm{O}_{3}$ & $\mathrm{CHCl}_{3}$ & 4.0 & 57 & 36 \\
5 & $\mathrm{FeCl}_{3} / \mathrm{Al}_{2} \mathrm{O}_{3}$ & $\mathrm{CH}_{3} \mathrm{CN}$ & 4.0 & 55 & 35 \\
6 & $\mathrm{FeCl}_{3} / \mathrm{Al}_{2} \mathrm{O}_{3}$ & DMF & 2.0 & 86 & 11 \\
$7^{\mathrm{c}}$ & $\mathrm{FeCl}_{3} / \mathrm{Al}_{2} \mathrm{O}_{3}$ & DMF & 2.0 & 59 & 37 \\
\hline
\end{tabular}

${ }^{a}$ Stirred at $25^{\circ} \mathrm{C}$, o-phenylenediamine $1.0 \mathrm{mmol}$ and benzaldehyde $1.0 \mathrm{mmol}, \mathrm{FeCl}_{3} / \mathrm{Al}_{2} \mathrm{O}_{3} 0.1 \mathrm{mmol}$ (based on $\mathrm{FeCl}_{3}$ ); ${ }^{b}$ Isolated yields. ${ }^{c}$ Operated in nitrogen atmosphere

To verify the efficiency of catalyst loading, we have investigated the effect of the amount of $\mathrm{FeCl}_{3} / \mathrm{Al}_{2} \mathrm{O}_{3}$ on the reaction (Table 2). The present procedure afforded $\mathbf{3 a}$ in $85 \%$, $86 \%$ and $81 \%$ yield when the amount of $\mathrm{FeCl}_{3} / \mathrm{Al}_{2} \mathrm{O}_{3}$ was $0.05 \mathrm{mmol}, 0.10 \mathrm{mmol}$ and 0.15 mmol respectively. So we chose $0.1 \mathrm{mmol} \mathrm{FeCl}{ }_{3} / \mathrm{Al}_{2} \mathrm{O}_{3}$ as the optimum amount.

The effect of recycled catalyst was also examined. At the end of the reaction, the catalyst was separated by filtration, thoroughly washed with ethyl acetate and reused under similar conditions. As shown by the formation of 2-phenyl-1 $H$-benzimidazole (3a), there was an appreciable loss in the activity in the reuse of these catalysts $(81 \%$ on the second run for $10 \mathrm{~h}$ 
and $58 \%$ on the third run for $10 \mathrm{~h}$, Entries 6,7$)$. This is expected mostly because of the leaching of the active catalyst component (i.e. iron) in the entire treatment process ${ }^{32}$. Further work is necessary to strongly bind the active component on the support.

Table 2. The effect of $\mathrm{FeCl}_{3} / \mathrm{Al}_{2} \mathrm{O}_{3}$ on the synthesis of 2-phenyl-1H-benzimidazole (3a) in DMF

\begin{tabular}{ccccc}
\hline Entry & $\begin{array}{c}\text { Catalyst, } \\
\text { mmol }\end{array}$ & Time, h & Yield $^{\mathrm{b}}(\mathbf{3 a}), \%$ & Yield $^{\mathrm{b}}(\mathbf{4 a}), \%$ \\
\hline 1 & 0.1 & 2.0 & 86 & 11 \\
$2^{\mathrm{c}}$ & 0.1 & 0.8 & 85 & 10 \\
3 & 0.05 & 5.0 & 85 & 15 \\
4 & 0.15 & 1.0 & 81 & 17 \\
$5^{\mathrm{d}}$ & 0.1 & 1.1 & 61 & 29 \\
$6^{\mathrm{e}}$ & 0.1 & 10 & 81 & 5 \\
$7^{\mathrm{f}}$ & 0.1 & 10 & 58 & 35 \\
\hline
\end{tabular}

${ }^{a}$ Stirred at $25^{\circ} \mathrm{C}, \mathrm{FeCl}_{3} / \mathrm{Al}_{2} \mathrm{O}_{3}$ was 0.1 mmol (based on $\mathrm{FeCl}$ ) $;{ }^{b}$ Isolated yields; ${ }^{c}$ Stirred at $60^{\circ} \mathrm{C} ;{ }^{d}$ The molar ratio of o-phenylenediamine/benzaldehyde was 1:2; ${ }^{e}$ First recycled $\mathrm{FeCl}_{3} / \mathrm{Al}_{2} \mathrm{O}_{3} ;{ }^{f}$ Second recycled $\mathrm{FeCl}_{3} / \mathrm{Al}_{2} \mathrm{O}_{3}$;

Using the present method, a number of 2-substituted arylbenzimidazoles (3a-3k) were synthesized from the condensation of $o$-phenylenediamine with a series of aromatic aldehydes in excellent yields catalyzed by $\mathrm{FeCl}_{3} / \mathrm{Al}_{2} \mathrm{O}_{3}$ in DMF. As shown in Table 3, the method was found to be equally effective for aldehydes bearing either electron-donating (Entries 4, 8) or electronwithdrawing substituents (Entry 7). It was found that the reaction time became longer when 2-substituted aromatic aldehydes were employed for the reaction (Entries 2, 5). We assumed that 2-substituents steric property hindered the intermediate imine from further cyclization. Encouraged by these results, the condensation of heteroaryl aldehyde such as furfuraldehyde (2j) and $o$-phenylenediamine (1) was examined to extend the scope of this method, and 2-(2'-furanyl phenyl)benzimidazole (3j) was obtained in moderate yield (74\%) within $4.7 \mathrm{~h}$ (Entry 10).

Table 3. Synthesis of 2-substituted benzimidazole derivatives $3(\mathbf{a}-\mathbf{k})^{\text {a }}$

\begin{tabular}{cccccc}
\hline Entry & $\mathrm{Ar}$ & Time/h & Product & Yield $^{\mathrm{b}}(\mathbf{3}) / \%$ & $\mathrm{~m} . \mathrm{p} . /^{\circ} \mathrm{C}(\mathrm{Lit})$ \\
\hline 1 & $\mathrm{C}_{6} \mathrm{H}_{5}$ & 2.0 & $\mathbf{3 a}$ & 86 & $291(292)^{27}$ \\
2 & $2-\mathrm{ClC}_{6} \mathrm{H}_{4}$ & 6.5 & $\mathbf{3 b}$ & 97 & $233-235(234)^{27}$ \\
3 & $3-\mathrm{ClC}_{6} \mathrm{H}_{4}$ & 3.3 & $\mathbf{3 c}$ & 83 & $232-233(236-238)^{24}$ \\
4 & $4-\mathrm{MeOC}_{6} \mathrm{H}_{4}$ & 3.2 & $\mathbf{3 d}$ & 81 & $224-226(226)^{27}$ \\
5 & $2-\mathrm{NO}_{2} \mathrm{C}_{6} \mathrm{H}_{4}$ & 11 & $\mathbf{3 e}$ & 96 & $256-258(261-263)^{24}$ \\
6 & $3-\mathrm{NO}_{2} \mathrm{C}_{6} \mathrm{H}_{4}$ & 4.3 & $\mathbf{3 f}$ & 84 & $207-208(204-205)^{24}$ \\
7 & $4-\mathrm{NO}_{2} \mathrm{C}_{6} \mathrm{H}_{4}$ & 2.6 & $\mathbf{3 g}$ & 98 & $314-316(316)^{27}$ \\
8 & $4-\mathrm{MeC}_{6} \mathrm{H}_{4}$ & 2.4 & $\mathbf{3 h}$ & 89 & $266-269(270)^{27}$ \\
9 & $4-\mathrm{Me}_{2} \mathrm{NC}_{6} \mathrm{H}_{4}$ & 5.9 & $\mathbf{3 i}$ & 91 & $238-240(233-236)^{8}$ \\
10 & $2-\mathrm{Furanyl}^{8}$ & 4.7 & $\mathbf{3 j}$ & 74 & $283-285(288)^{27}$ \\
11 & $3,4-\mathrm{OCH}_{2} \mathrm{OC}_{6} \mathrm{H}_{3}$ & 3.8 & $\mathbf{3 k}$ & 92 & $247-249(246)^{8}$ \\
\hline \multicolumn{5}{c}{}
\end{tabular}

\section{Conclusion}

In summary, we have found a practical procedure for the preparation of 2-substituted benzimidazoles catalyzed by $\mathrm{FeCl}_{3} / \mathrm{Al}_{2} \mathrm{O}_{3}$ stirred at ambient temperature. Our procedure is characterized by milder conditions, shorter reaction time, higher yield and involvement of non toxic and expensive catalyst. 


\section{Acknowledgment}

We thank Natural Science Foundation of Hebei Province (B2011201072), National Natural Science Foundation of China (20806018), the Science Project of the Hebei Education Department (ZD200910) and Foundation of Hebei University (2009-163).

\section{References}

1. Hirashima S, Suzuki T, Ishida T, Noji S, Ando I, Komatsu M, Ikede S and Hashimoto H, J Med Chem., 2006, 49, 4721.

2. Roth T, Morningstar M L, Boyer P L, Hughes S H, Buckheit R W Jr and Michejda C J, J Med Chem., 1997, 40, 4199.

3. Migawa M T, Girardet J L, Walker J A, Koszalka G W, Chamberlain S D, Drach J C and Townsend L B, J Med Chem., 1998, 41, 1242.

4. Tamm I, Science, 1954, 120, 847.

5. Wright J B, Chem Rev., 1951, 48, 397.

6. Fairley T A, Tidwell R R, Donkor I, Naiman N A, Ohemeng K A, Lombardy R J, Bentley J A and Cory M, J Med Chem., 1993, 36, 1746.

7. Bougrin K, Loupy A and Soufiaoui M, Tetrahedron, 1998, 54, 8055.

8. Chakrabarty M, Karmakar S, Mukherji A, Arima S and Harigaya Y, Heterocycl.,, 2006, 68, 967.

9. Gogoi P and Konwar D, Tetrahedron Lett., 2006, 47, 79.

10. Trivedi R, De S K and Gibbs R A, J Mol Cat A: Chem., 2006, 245, 8.

11. Nagata K, Itoh T, Ishikawa H and Ohsawa A, Heterocycl., 2003, 61, 93.

12. Kawashita Y, Nakamichi N, Kawabata H and Hayashi M, Org Lett., 2003, 5, 3713.

13. Singh M P, Sasmal S, Lu W and Chatterjee M N, Synthesis, 2000, 1380.

14. Bahrami K, Khodaei M M and Kavianinia I, Synthesis, 2007, 547.

15. Das B, Kanth B S, Reddy K R and Kumar A S, J Heterocycl Chem., 2008, 45, 1499.

16. Lee K J and Janda K D, Can J Chem., 2001, 79, 1556.

17. Sharghi H, Asemani O and Khalifeh R, Synth Commun., 2008, 38, 1128.

18. Ma H Q, Wang Y L, Li J P and Wang J Y, Heterocycles, 2007, 71, 135.

19. Das B, Holla H and Srinivas Y, Tetrahedron Lett., 2007, 48, 61.

20. Du L H and Wang Y G, Synthesis, 2007, 675.

21. Lin S N and Yang L H, Tetrahedron Lett., 2005, 46, 4315.

22. Chari M A, Shobha D, Kenawy E R, Al-Deyab S S, Subba Reddy B V and Vinu Ajayan, Tetrahedron Lett., 2010, 51, 5195.

23. Ruiz V R, Corma A and Sabater M J, Tetrahedron, 2010, 66, 730.

24. Gadekar L S, Arbad B R and Lande M K, Chin Chem Lett., 2010, 21, 1053.

25. Speier G and Parkanyi L, J Org Chem., 1986, 51, 218.

26. Ouyang J, Ouyang C G, Fujii Y, Nakano Y, Shoda T and Nagano T, J Heterocycl Chem., 2004, 41, 359.

27. Alloum A B, Bougrin K and Soufiaoui M, Tetrahedron Lett., 2003, 44, 5935.

28. Bahrami K, Khodaei M M and Nejati A, Green Chem., 2010, 12, 1237.

29. Bergbreiter D E and Lalonde J J, J Org Chem., 1987, 52, 1601.

30. Jiang Y, Wang J Y, Chen J H, Wang W J, Yan H, Zhang X X, Wang C, Zhang G L and Li B G, Acta Chim Sinica, 2007, 65, 1925.

31. Li T S, Duan H Y, Li B Z, Tewari B B and Li S H, J Chem Soc., Perkin Trans 1, 1999, 1, 291.

32. Salavati-Niasari M, Hasanalian J and Najafian H, J Mol Catal A: Chem., 2004, 209, 209.

33. Shi J H, Zhou L, Wang L Z and Yan W, J Zhejiang Univ Tech., 2006, 34, 360. 


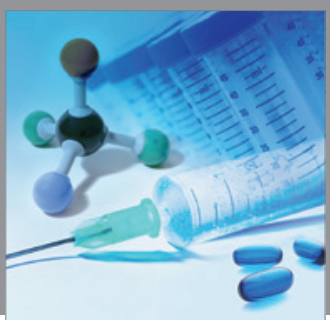

International Journal of

Medicinal Chemistry

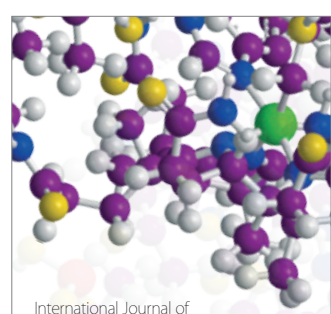

Carbohydrate Chemistry

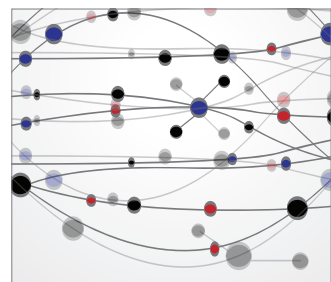

The Scientific World Journal
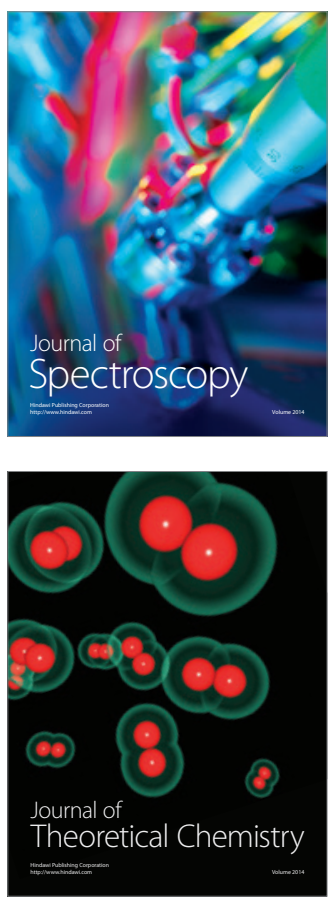
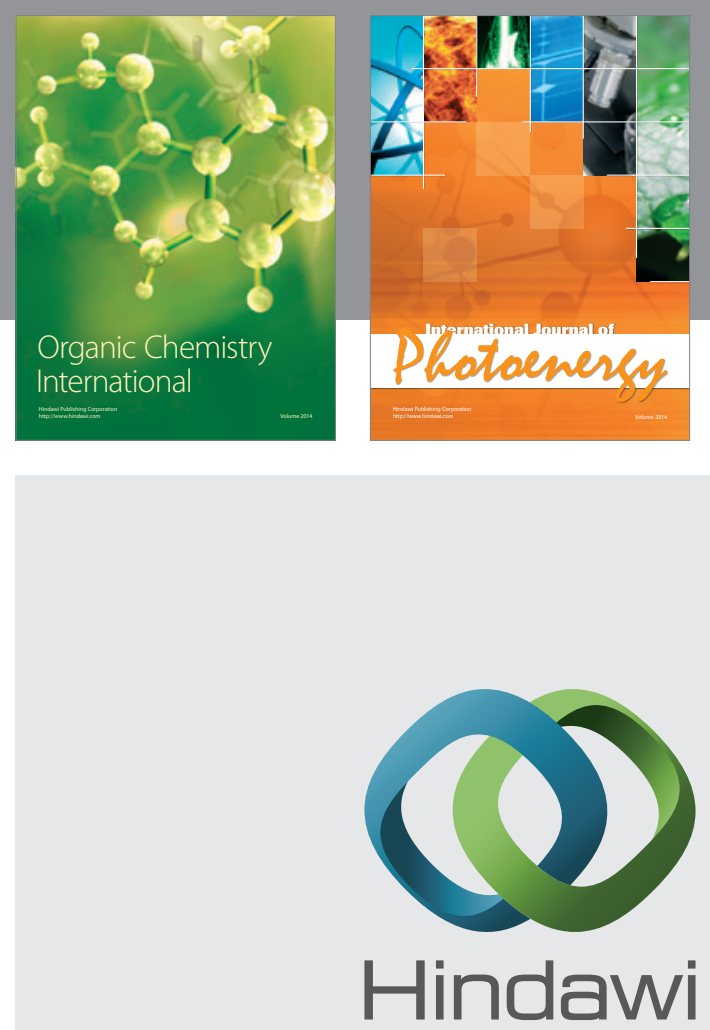

Submit your manuscripts at

http://www.hindawi.com
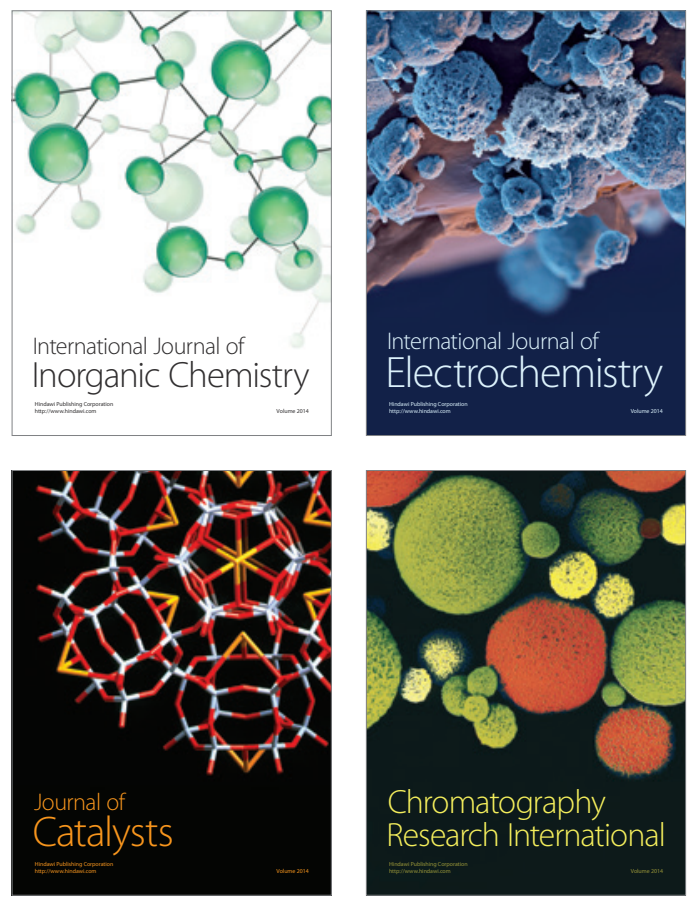
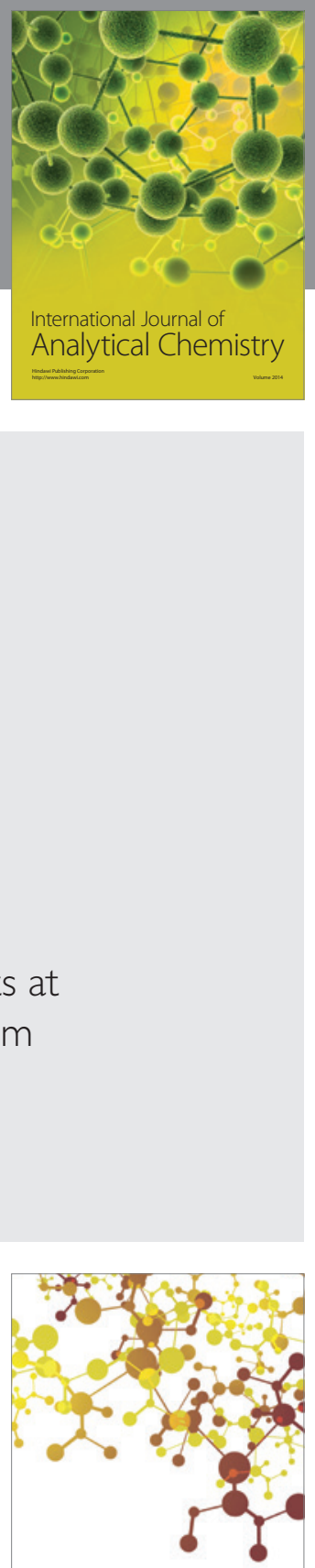

Journal of

Applied Chemistry
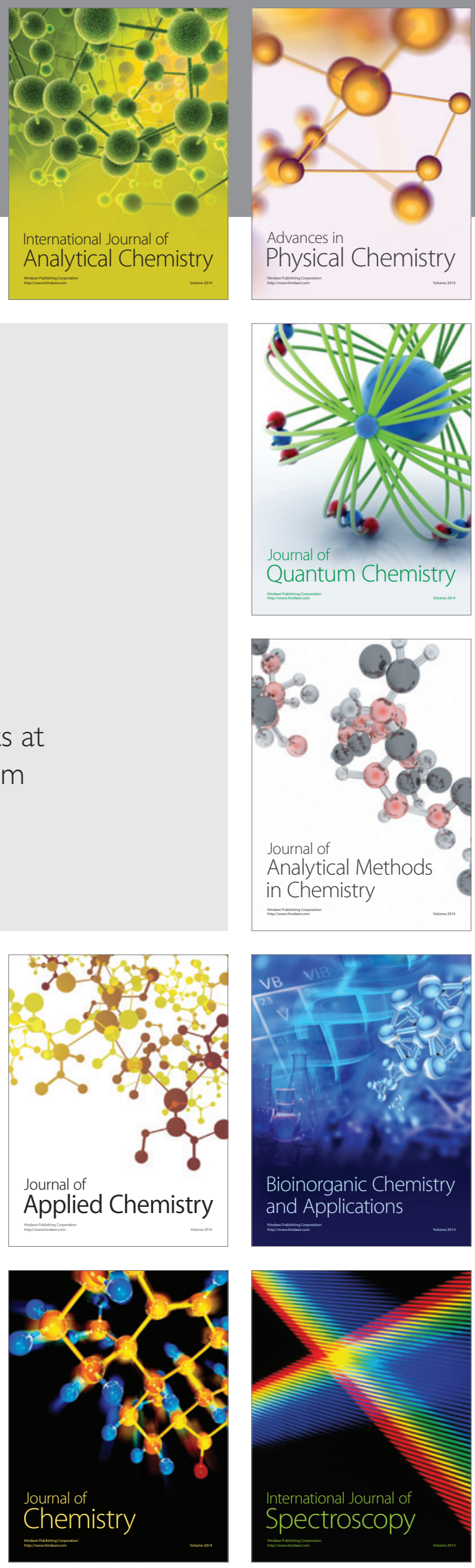